\title{
Re-ranking of corporate governance ratings of BIST XKURY companies based on TOPSIS method of ordering
}

\author{
Veysel Kula ${ }^{1, ~ *, ~ E n d e r ~ B a y k u t ~}{ }^{2, *}$ \\ ${ }^{1}$ Department of International Trade and Finance, AfyonKocatepe University, Afyonkarahisar, Turkey \\ ${ }^{2}$ Department of Management in English, AfyonKocatepe University, Afyonkarahisar, Turkey
}

\section{Email address:}

kula@aku.edu.tr (V. Kula), ebaykut@aku.edu.tr (E. Baykut)

\section{To site this article:}

Veysel Kula, Ender Baykut. Re-ranking of Corporate Governance Ratings of BIST XKURY Companies Based on TOPSIS Method of Ordering. International Journal of Economics, Finance and Management Sciences.Vol. 2, No.1, 2014, pp. 103-110.

doi: $10.11648 /$ j.ijefm.20140201.21

\begin{abstract}
This study aims at re-defining the corporate governance ratings of companies listed in Borsa Istanbul Corporate Governance Index (BIST XKURY). Corporate governance ratings are computed by taking the weighted average of four sub-categories, with the weights subjectively determined by the Capital Market Board. As each company in the index has the overall rating of more than eight, the ratings are only narrowly dispersed within a thin rating band of eight to ten, lacking ability in providing decision makers helpful information in terms of comparative strength of companies. This problem could be addressed by the use of TOPSIS based ranking.Using the ratings of 46 companies for 2013 in the index, TOPSIS method provides a new rank order that has a richer information content. By means of new scores, decision makers could evaluate how far companies closer to the ideal positive and negative solutions.
\end{abstract}

Keywords: Borsa Istanbul, Corporate Governance Index, Corporate Governance Ratings, TOPSIS Method

\section{Introduction}

Several stakeholders get involved in the operation of companies, each trying to maximize their own interests. Maximization of the interests of a party is most of the time achieved at the expense of interests of the others. For a long term survival of companies, a balance must be instituted to satisfy a variety of stakeholders. Especially in the view of recent financial crises and corporate scandals, corporate governance is regarded as a solution that has come to prominence in the last decades.

Corporate governance achieve the intended outcomes by contemporaneously addressing conflicting interests of several parties. Corporate governance is defined by OECD [1] as a set of procedures and processes to which an organization is directed and controlled. Though the directing and collecting activities are carried out for the benefit of several entities, the narrowest focus is on the interests of "shareholders" [2].The focus is widened by including other numerous entities. For example, in specifying the beneficiaries of corporate, Shleifer and Vishny [3] go beyond mere shareholders and cover all "suppliers of finance" to corporations. More comprehensive definitions of corporate governance target interests of all other possible stakeholders in addition to the suppliers of finance. Definition of OECD [1, 4], for example, covers shareholders, managers, employees, customers, creditors, fund suppliers and the state as stakeholders.

The first international institutional attempt to establish corporate governance principles was made by OECD with the participation of 30 counties in 1998. OECD Principles of Corporate Governance have served as the main source for other institutions in their regulations on the field. In July 2003, for example, CMB of Turkey issued the Corporate Governance Principles with the purpose of enhancing the corporate governance regulations for listed companies. $\mathrm{CMB}$ principles were established mainly in accordance with OECD Corporate Principles, taking, as well, into consideration the particular conditions of Turkey. CMB Corporate Governance Principles were revised in 2005. The CMB principles are based on the principle of "comply or explain". In other words, the implementation of the principles is optional and companies should disclose the extent of compliance and explain the reasons why some of the principles are not adopted. The implementation status of the principles should be disclosed in Corporate Governance Compliance Report that is included in the 
annual report as a separate section [5].

Another important step regarding the development of corporate governance in Turkey is to set up a Corporate Governance Index. BorsaIstanbul (BIST) Corporate Governance Index (XKURY) is the index in which the companies that apply CMB Corporate Governance Principles are included. BIST XKURY aims to measure the price and return performances of companies traded on Borsa Istanbul Markets (except companies in Watch list Companies Market and List C) with a corporate governance rating of minimum 7 over 10 as a whole and minimum of 6.5 for each main section. The corporate governance rating is determined by the rating institutions incorporated by $\mathrm{CMB}$ in its list of rating agencies as a result of their assessment of the company's compliance with the corporate governance principles. Corporate Governance Index started to be calculated on 31.08.2007 [6].As of the January 2014, the number of companies in the XKURY has reached 47.

There are five rating companies that meet the criteria set in the Communiqué on Principles Regarding Ratings and Agencies(Serial: VIII, No: 51), issued by CMB [7].The institutions that are authorized for corporate governance rating are;

- SAHA Corporate Governance and Credit Rating Services Inc.

- Kobirate International Credit Rating and Corporate Governance Services Inc.

- JCR Eurasi Rating Inc.

- Turkish Credit Rating Inc.

- ISS- Corporate Governance Rating-Risk Metrics Group, Inc.

By the scores given to the firms, these firms try to help investors better assess and manage risks related to the financial markets [8].
Corporate governance rating of a company is granted by rating institutions upon the request of a company. Ratings demonstrate how a company complies with advisory rules of CMB Corporate Governance Principles. Corporate governance ratings are granted out of 10 and Corporate Governance Rating Reports are published by the rating agencies [5].

Corporate governance ranking is, in fact, rather a recent issue for Turkish firms. Although the new regulations in Turkey encourage the firms to get corporate ratings, firms are not obliged to get them. It is those firms which trade their stocks in the Borsa Istanbul (BIST) that are interested in governance ratings, while corporate governance rating seems as a luxury for firms that do not trade their stocks publicly [8].However, the governance scores have been becoming increasingly popular [9]. In addition to the listed companies, non-listed companies can apply for corporate governance rating agencies for rating, too.

The Corporate Governance Rating is broken up into four sub-categories which measure the major components of corporate governance: (a)shareholders,(b)public disclosure and transparency, (c)stakeholders, and (d)board of directors. Each of the sub-indices is weighted to produce the finaloverall corporate governance rating. The weights are subjectively specified by the CMB as follows: $25 \%$ for shareholders, $25 \%$ for public disclosure and transparency, $15 \%$ for stakeholders and 35\% for board of directors. The weights are used to indicate the importance of each of these components to the overall corporate governance rating.

A rating between 1-10 is assigned to the overall level of compliance with the principles of corporate governance as well as to the four categories [10].Definitions of ratings are provided in Table.1.

Table 1. Definitions of CorporateGovernanceRatings.

\begin{tabular}{ll}
\hline Rating & Definition \\
\hline $9-10$ & $\begin{array}{l}\text { The company performs very well in terms of Capital Markets Board's corporate governance principles. It has, to varying degrees, identified } \\
\text { and actively managed all significant corporate governance risks through comprehensive internal controls and management systems. The } \\
\text { company's performance is considered to represent best practice, and it had almost no deficiencies in any of the areas rated. }\end{array}$ \\
& The company performs well in terms of Capital Markets Board's corporate governance principles and has qualified to be included in the \\
B - $8 \quad \begin{array}{l}\text { BIST's (Borsa Istanbul) Corporate Governance Index. It has, to varying degrees, identified all its material corporate governance risks and is } \\
\text { actively managing the majority of them through internal controls and management systems. During the rating process, minor deficiencies } \\
\text { were found in one or two of the areas rated. }\end{array}$ \\
$\begin{array}{l}\text { The company performs fair in terms of Capital Markets Board's corporate governance principles. It has, to varying degrees, identified the } \\
\text { majority of its material corporate governance risks and is beginning to actively manage them. Management accountability is considered in } \\
\text { accordance with national standards but may be lagging behind international best practice. During the ratings process, minor deficiencies } \\
\text { were identified in more than two of the areas rated. }\end{array}$ \\
$\begin{array}{l}\text { The company performs weakly as a result of poor corporate governance policies and practices. The company has, to varying degrees, } \\
\text { identified its minimum obligations but does not demonstrate an effective, integrated system of controls for managing related } \\
\text { risks. Assurance mechanisms are weak. The rating has identified significant deficiencies in a number (but not the majority) of areas rated. }\end{array}$ \\
$\begin{array}{l}\text { The company performs very weakly and its corporate governance policies and practices are overall very poor. The company shows limited } \\
\text { awareness of corporate governance risks, and internal controls are almost non-existent. Significant deficiencies are apparent in the majority } \\
\text { of areas rated and have led to significant material loss and investor concern. }\end{array}$
\end{tabular}


As depicted in Table.1, the rating of 1 (one) represents the weakest profile while the highest quality is represented by the rating of 10 (ten). In order to be included in the Borsa Istanbul (BIST) Corporate Governance Index, a rating of 7 or more is required. The overall rating as well as the ratings for the four main sections are disclosed to the public.

As of December 2013, there are 47 companies in BIST XKURY index. Of those companies, 46 have the corporate governance ratings for 2013.

As the corporate governance ratings of the companies in the index are presently all more than eight, there is not a wider dispersion of the scores, making it not possible to reasonably differentiate the firms as strong or weak. The ratings are far away from providing a comparative interplay of companies based on the scores, other than merely reporting the scores. Those shortcomings could be handled by a multi-criteria ordering method called TOPSIS, acronym for Technique for Order Preference by Similarity to Ideal Solution. Taking into account the positive and negative ideal solutions, TOPSIS method produces scores that illuminate the relative power of each company.

The next section of the study will provide literature review. Section three will present the data and methodology. The study will conclude by Section. 4 .

\section{Literature Review}

There are several studies using TOPSIS model in variousperformanceevaluation andselection decisions. A study on Taiwanese companies [11], for example, used TOPSIS model for financial performance evaluation of five airline companies in Taiwan. Similarly, other study [12] on top-50 listed companies on Tehran Stock Exchange produced, by means of TOPSIS method, the ranking of the companies for the years 2009- 2011 in terms of their liquidity, operation, leverage and profitability ratios. There is a study [13] which evaluated the financial performances of Turkish Banks during 2002-2011 periods by using TOPSIS.TOPSIS method is also used as a solution to a hypothetical supplier selection problem [14] and in selecting a better performing branch of a parent company in Turkey [15].

When it comes to the BIST companies, there seems to be just a limited number of studies using TOPSIS model. A study [16] attempted to use a multi-criteria decisionmaking model to measure and compare the financial performances of thirteen technology firms trading in Borsa Istanbul. These firms are examined and assessed in terms of ten financial ratios which are combined to obtain a financial performance score by using TOPSIS.

Another study [17] in 2011 evaluated the organizational performances of BIST XKURY companies comparing corporate governance ratings with TOPSIS model scores produced using a set of financial ratios.

TOPSIS is an approach to identify an alternative which is closest to the ideal solution and farthest to the negative ideal solution in a multi-dimensional computing space. Apart from being simple and rational, TOPSIS has the advantage of standing on its own as a decision-making tool [18]. Furthermore, this method has a clear logic that represents the rationale of human choice, produces a scalar value that accounts for both the best and worst alternatives, and is able to measure the relative performance for each alternative in a simple mathematical form [19].

Subjective weights are essential inputs in the TOPSIS method. The alternative sets of weights are usually developed in three ways: equal weights, weights generated by ordinal rank, and weights generated by regression [19].Hence, the weights can change in each study based on the arbitrary choice by authors. In the present study, however, subjective weights pre-determined by the CMB of Turkey are used. As mentioned in introductory part of the study, the standard subjective weights for each corporate governance sub-categories are as follows: shareholders (\%25), public disclosure and transparency (\%25), stakeholders $(\% 15)$ and board of directors (\%35). The subjective weights assigned by CMB will serve as primary input in conducting TOPSIS method.

The next section of the study will provide a detailed explanation about the TOPSIS method.

\section{Data and Methodology}

Corporate governance ratings reflect the extent to which the companies comply with corporate governance practices. In Borsa Istanbul, companies with the corporate governance ratings exceeding the threshold of seven are included in Corporate Governance Index. As of December 2013, the number of companies in the XKURY has reached 47. One firm with no rating for 2013 was excluded from the study. The web sites of the companies in the index and of rating companies are used to retrieve the ratings for 2013. The rank order of the corporate governance ratings of 46 companies in BIST XKURY index for 2013 is reported in Table.2. TSKB, Turkish Industrial Development Bank, is placed at the top of the list with the overall score of 9.403. Tav Airport ranks second in the list, followed by Tupras. Twenty-eight companies have the overall rating of more than 9.00 in the list. Table.2also provides the corporate governance ratings for four sub-categories. All subcategories have the corporate governance rating of minimum 7.00. The rankings of four sub-categories together with the relative weights will be processed by TOPSIS modeling to produce more meaningful information for use by decision makers.

TOPSIS method was originally developed in 1981 by Yoon and Hwang [20]. It is based upon the concept that the chosen alternative should have the shortest distance from the ideal solution and the farthest from the negative-ideal solution. 
Table.2. Corporate Governance Ratings of BIST XKURY Companies for 2013.

\begin{tabular}{|c|c|c|c|c|c|c|}
\hline \multirow{3}{*}{ Company } & \multicolumn{6}{|c|}{ Corporate Governance Ratings } \\
\hline & \multirow[b]{2}{*}{$\begin{array}{l}\text { Rank } \\
\text { Order }\end{array}$} & \multirow[b]{2}{*}{ Overall Score } & \multicolumn{4}{|c|}{ Corporate Governance Ratings for Categories } \\
\hline & & & Shareholders & $\begin{array}{l}\text { Public Disclosure } \\
\text { and Transparency }\end{array}$ & Stakeholders & $\begin{array}{l}\text { Board of } \\
\text { Directors }\end{array}$ \\
\hline & & $100 \%$ & (Relative Weights) & & & \\
\hline & & $100 \%$ & $25 \%$ & $25 \%$ & $15 \%$ & $35 \%$ \\
\hline TSKB & 1 & 9,403 & 8,865 & 9,708 & 9,544 & 9,508 \\
\hline Tav Airport & 2 & 9,397 & 9,262 & 9,659 & 9,453 & 9,131 \\
\hline Tupraş & 3 & 9,343 & 8,863 & 9,252 & 9,267 & 9,782 \\
\hline AnadoluEfes & 4 & 9,33 & 8,958 & 9,947 & 9,167 & 9,225 \\
\hline YapiKredi & 5 & 9,322 & 9,468 & 9,124 & 9,381 & 9,334 \\
\hline Arçelik & 6 & 9,28 & 8,98 & 9,19 & 9,67 & 9,39 \\
\hline Aygaz & 7 & 9,271 & 8,976 & 9,185 & 9,576 & 9,413 \\
\hline Akbank & 8 & 9,237 & 9,381 & 9,318 & 9,24 & 9,074 \\
\hline VakifMenkul & 9 & 9,21 & 9,077 & 9,5 & 9,231 & 8,934 \\
\hline Halkbank & 10 & 9,205 & 9,403 & 9,411 & 9,591 & 8,752 \\
\hline Coca Cola & 11 & 9,201 & 8,157 & 9,542 & 9,833 & 9,435 \\
\hline Enka & 12 & 9,197 & 8,93 & 9,536 & 8,727 & 9,347 \\
\hline Doğan & 13 & 9,181 & 8,936 & 9,332 & 9,293 & 9,201 \\
\hline Pinar Et ve Un & 14 & 9,159 & 8,2 & 9,255 & 9,572 & 9,6 \\
\hline Pinar Süt & 15 & 9,149 & 8,112 & 9,255 & 9,652 & 9,6 \\
\hline Tofaş & 16 & 9,139 & 8,104 & 9,352 & 9,92 & 9,39 \\
\hline İş Leasing & 17 & 9,114 & 8,557 & 9,926 & 8,783 & 9,074 \\
\hline TürkTraktör & 18 & 9,104 & 8,09 & 9,206 & 9,767 & 9,473 \\
\hline Otokar & 19 & 9,103 & 8,958 & 9,279 & 9,797 & 8,583 \\
\hline Şekerbank & 20 & 9,095 & 9,321 & 9,107 & 9,64 & 8,525 \\
\hline VestelElektronik & 21 & 9,09 & 9,138 & 9,287 & 9,085 & 8,785 \\
\hline Hürriyet & 22 & 9,09 & 9,162 & 9,391 & 9,105 & 8,589 \\
\hline Egeli\& Co. Yatirim Holding & 23 & 9,08 & 8,09 & 9,285 & 9,067 & 9,648 \\
\hline Aselsan & 24 & 9,071 & 8,09 & 9,919 & 9,485 & 8,987 \\
\hline İşYatirim & 25 & 9,06 & 8,88 & 9,4 & 8,79 & 9,06 \\
\hline DoğuşOtomotiv & 26 & 9,05 & 9,167 & 9 & 8,974 & 9,032 \\
\hline DoğanYayin Holding & 27 & 9,034 & 8,917 & 9,824 & 7,946 & 8,699 \\
\hline Y\&Y YatirimOrtakliği & 28 & 9,024 & 8,974 & 9,405 & 9,275 & 8,391 \\
\hline Park Elektrik & 29 & 8,98 & 8,786 & 9,665 & 8,793 & 8,708 \\
\hline Dentaş & 30 & 8,973 & 8,446 & 9,41 & 9,364 & 8,871 \\
\hline Bank Asya & 31 & 8,924 & 7,936 & 9,477 & 9,848 & 8,839 \\
\hline Logo & 32 & 8,912 & 8,801 & 8,645 & 9,056 & 9,122 \\
\hline Petkim & 33 & 8,91 & 8,75 & 9,333 & 9,487 & 8,468 \\
\hline Global Yatirim Holding & 34 & 8,86 & 8,869 & 9 & 8,974 & 8,689 \\
\hline İşGyo & 35 & 8,81 & 8,78 & 9,16 & 8,32 & 8,79 \\
\hline Türk Telekom & 36 & 8,802 & 8,09 & 9,899 & 8,433 & 8,685 \\
\hline Yazicilar & 37 & 8,775 & 8,021 & 9,306 & 9,643 & 8,266 \\
\hline GarantiFaktoring & 38 & 8,76 & 8,611 & 9,167 & 8,718 & 8,607 \\
\hline Turkas & 39 & 8,75 & 8,472 & 9 & 8,974 & 8,525 \\
\hline Prysmain & 40 & 8,655 & 8,936 & 8,204 & 9,167 & 8,556 \\
\hline Albaraka & 41 & 8,62 & 8,38 & 9,1 & 8,55 & 8,22 \\
\hline Boyner & 42 & 8,613 & 8,936 & 8,334 & 9,242 & 8,295 \\
\hline GarantiYatirimOrtakliği & 43 & 8,39 & 8,154 & 8,667 & 8,718 & 8,033 \\
\hline İhlas Holding & 44 & 8,15 & 8,05 & 8,86 & 7,06 & 8,18 \\
\hline İhlasEvAletleri & 45 & 8,05 & 7,55 & 8,59 & 7,61 & 8,21 \\
\hline CreditwestFaktoring & 46 & 8,03 & 8,12 & 8,29 & 7,53 & 7,87 \\
\hline
\end{tabular}

Assuming that each attribute takes the monotonically increasing (or decreasing) utility; then it is easy to locate the "ideal" solution which is composed of all best attribute values attainable, and the "negative-ideal" solution composed of all worst attribute values attainable. One approach is to take an alternative which has the (weighted) minimum Euclidean distance to the ideal solution in a geometrical sense [20]. 
The TOPSIS method evaluates the following decision matrix which contains malternatives associated with $\mathrm{n}$ attributes (or criteria).

$$
A_{i j}=\left[\begin{array}{cccc}
x_{11} & x_{12} & \ldots & x_{1 n} \\
x_{21} & x_{22} & \ldots & x_{2 n} \\
\cdot & & & \cdot \\
\cdot x_{i 1} & x_{i 2} & x_{i j} & \cdot x_{i n} \\
\cdot & & & \cdot \\
x_{m 1} & x_{m 2} & \ldots & x_{m n}
\end{array}\right]
$$

where;

$A_{i}=$ the $i^{\text {th }}$ alternative considered,

$x_{i j}=$ the numerical outcome of the $i^{t h}$ alternative with respect to the $j^{\text {th }}$ criterion.

The larger the attribute outcomes, the greater the preference for the "benefit" criteria, and the less the preference for the "cost" criteria. Further, any outcome which is expressed in a non-numerical way should be quantified through the appropriate scaling technique. Since all criteria cannot be assumed to be of equal importance, the method receives a set of weights from the decision maker. For the sake of simplicity the proposed method ispresented as a series of successive steps [20];

\section{Step1. ConstructThe Normalized Decision Matrix}

This process tries to transform the various attribute dimensions into non-dimensional attributes, which allows comparison across the attributes. One way is to take the outcome of each criterion divided by the norm of the total outcome vector of the criterion at hand. An element $r_{i j}$ of the normalized decision matrix $\mathrm{R}$ can be calculated as;

$$
r_{i j}=\frac{x_{i j}}{\sqrt{\sum_{i=1}^{m} x_{i j}^{2}}} \text { Consequently, each attribute has the same }
$$

unit length of vector.

\section{Step 2. Construct The Weighted Normalized Decision Matrix:}

A set of weights $\mathrm{w}=\left(w_{1}, w_{2} \ldots \ldots ., w_{j}, \ldots \ldots . w_{n}\right)$, $\sum_{j=1}^{n} w_{j}=1$, from the decision maker is accommodated to the decision matrix in this step. This matrix can be calculated by multiplying each column of the matrixR with its associated weight $w_{j}$. Therefore, the weighted normalized decision matrix $\mathrm{V}$ is equal to;

$$
V=\left[\begin{array}{cccc}
w_{1} r_{11} & w_{2} r_{12} & \ldots & w_{n} r_{1 n} \\
w_{1} r_{21} & w_{2} r_{22} & \ldots & w_{n} r_{2 n} \\
\cdot & & & \cdot \\
\cdot & & & \cdot \\
\cdot & & & \cdot \\
w_{1} r_{m 1} & w_{2} r_{m 2} & \ldots & w_{n} r_{m n}
\end{array}\right]
$$

\section{Step3. Determine Ideal and Negative-Ideal Solutions}

Let the two artificial alternatives $A^{*}$ and $A^{-}$be defined as;

$$
A^{*}=\left\{\left(\max _{i} v_{i j} \mid j \in J\right),\left(\min _{i} v_{i j} \mid j \in J^{\prime}\right\}\right.
$$

$\mathrm{i}=1,2,3, \ldots \ldots . \mathrm{m}\}$

$$
\begin{gathered}
=\left\{v_{1}^{*}, v_{2}^{*}, \ldots, v_{n}^{*}\right\} \\
A^{-}=\left\{\left(\min _{i} v_{i j} \mid j \in J\right),\left(\max _{i} v_{i j} \mid j \in J^{\prime}\right\}\right.
\end{gathered}
$$

$\mathrm{i}=1,2,3, \ldots \ldots \ldots \mathrm{m}\}$

$$
=\left\{v_{1}^{-}, v_{2}^{-}, \ldots, v_{n}^{-}\right\}
$$

where; $\mathrm{j}=\{\mathrm{j}=1,2, \ldots, \mathrm{n} \mid \mathrm{j}$ associated with benefit criteria $\}$ $j^{l}=\{\mathrm{j}=1,2, \ldots, \mathrm{n} \mid \mathrm{j}$ associated with cost criteria $\}$

Then it is certain that the two created alternatives $A^{*}$ and $A^{-}$indicate the most preferable alternative (ideal solution) and the least preferable alternative (negative-ideal solution), respectively.

\section{Step4.Calculate the Separation Measure}

The separation between each alternative can be measured by the n-dimensional Euclidean distance. The separation of each alternative from the ideal one is then given by

$$
S_{i}^{*}=\sqrt{\sum_{j=1}^{n}\left(v_{i j}-v_{j}^{*}\right)^{2}} \mathrm{i}=1,2,3, \ldots \ldots \ldots, \mathrm{m} .
$$

Similarly, the separation from the negative-ideal one is given by

$$
S_{i}^{-}=\sqrt{\sum_{j=1}^{n}\left(v_{i j}-v_{j}^{-}\right)^{2}} \mathrm{i}=1,2,3, \ldots \ldots \ldots, \mathrm{m} .
$$

\section{Step5. CalculatetheRelativeClosenesstotheIdeal Solution}

The relative closeness of $A_{i}$ with respect to $A^{*}$ is defined as; 
Table.3. Comparison of TOPSIS Rankings with CG Rating Rankings.

\begin{tabular}{|c|c|c|c|c|c|c|}
\hline \multirow[t]{2}{*}{ Companies } & \multicolumn{3}{|c|}{$\begin{array}{l}\text { TOPSIS } \\
\text { Ranking }\end{array}$} & \multirow{2}{*}{$\begin{array}{c}\text { Diff. } \\
\text { B/w } \\
\text { Ranks }\end{array}$} & \multicolumn{2}{|c|}{$\begin{array}{c}\text { CG Rating } \\
\text { Ranking }\end{array}$} \\
\hline & & Score & Rank & & Rank & Score \\
\hline TSKB & & 0,808777 & 1 & 0 & 1 & 9,403 \\
\hline Tupraş & & 0,775518 & 2 & 1 & 3 & 9,343 \\
\hline Tav Airport & & 0,758423 & 3 & -1 & 2 & 9,397 \\
\hline YapiKredi & & 0,755676 & 4 & 1 & 5 & 9,322 \\
\hline AnadoluEfes & & 0,753095 & 5 & -1 & 4 & 9,33 \\
\hline Arçelik & & 0,749954 & 6 & 0 & 6 & 9,28 \\
\hline Aygaz & & 0,749836 & 7 & 0 & 7 & 9,271 \\
\hline Enka & & 0,721641 & 8 & 4 & 12 & 9,197 \\
\hline Akbank & & 0,710749 & 9 & -1 & 8 & 9,237 \\
\hline Doğan & & 0,706688 & 10 & 3 & 13 & 9,181 \\
\hline Coca Cola & & 0,675020 & 11 & 0 & 11 & 9,201 \\
\hline Pinar Et ve Un & & 0,673122 & 12 & 2 & 14 & 9,159 \\
\hline VakifMenkul & & 0,669089 & 13 & -4 & 9 & 9,21 \\
\hline Pinar Süt & & 0,662791 & 14 & 1 & 15 & 9,149 \\
\hline Halkbank & & 0,656032 & 15 & -5 & 10 & 9,205 \\
\hline Tofaş & & 0,649512 & 16 & 0 & 16 & 9,139 \\
\hline Egeli\&Co. Yatirim Holding & & 0,646229 & 17 & 6 & 23 & 9,08 \\
\hline İş Leasing & & 0,646112 & 18 & -1 & 17 & 9,114 \\
\hline İşYatirim & & 0,645853 & 19 & 6 & 25 & 9,06 \\
\hline TürkTraktör & & 0,643390 & 20 & -2 & 18 & 9,104 \\
\hline DoğuşOtomotiv & & 0,637870 & 21 & 5 & 26 & 9,05 \\
\hline VestelElektronik & & 0,612975 & 22 & -1 & 21 & 9,09 \\
\hline Aselsan & & 0,600947 & 23 & 1 & 24 & 9,071 \\
\hline Logo & .0 & 0,585378 & 24 & 8 & 32 & 8,912 \\
\hline Dentaş & 芑 & 0,581368 & 25 & 5 & 30 & 8,973 \\
\hline Otokar & $\stackrel{\infty}{\pi}$ & 0,580536 & 26 & -7 & 19 & 9,103 \\
\hline Hürriyet & $\overrightarrow{\widetilde{J}}$ & 0,579925 & 27 & -5 & 22 & 9,09 \\
\hline Şekerbank & $\frac{0}{0}$ & 0,578893 & 28 & -8 & 20 & 9,095 \\
\hline Park Elektrik & $\geqq$ & 0,575386 & 29 & 0 & 29 & 8,98 \\
\hline DoğanYayin Holding & ह & 0,551550 & 30 & -3 & 27 & 9,034 \\
\hline Bank Asya & $\mathscr{8}$ & 0,541526 & 31 & 0 & 31 & 8,924 \\
\hline Global Yatirim Holding & 9 & 0,532167 & 32 & 2 & 34 & 8,86 \\
\hline Y\&Y YatirimOrtakliği & $\overline{8}$ & 0,530122 & 33 & -5 & 28 & 9,024 \\
\hline Petkim & 8 & 0,527660 & 34 & -1 & 33 & 8,91 \\
\hline İşGyo & U & 0,522402 & 35 & 0 & 35 & 8,81 \\
\hline Türk Telekom & & 0,494809 & 36 & 0 & 36 & 8,802 \\
\hline GarantiFaktoring & & 0,485788 & 37 & 1 & 38 & 8,76 \\
\hline Prysmain & & 0,458232 & 38 & 2 & 40 & 8,655 \\
\hline Turkas & & 0,451607 & 39 & 0 & 39 & 8,75 \\
\hline Boyner & & 0,427934 & 40 & 2 & 42 & 8,613 \\
\hline Yazicilar & & 0,427095 & 41 & -4 & 37 & 8,775 \\
\hline Albaraka & & 0,367137 & 42 & -1 & 41 & 8,62 \\
\hline GarantiYatirimOrtakliği & & 0,286117 & 43 & 0 & 43 & 8,39 \\
\hline İhlas Holding & & 0,217040 & 44 & 0 & 44 & 8,15 \\
\hline İhlasEvAletleri & & 0,163533 & 45 & 0 & 45 & 8,05 \\
\hline CreditwestFaktoring & & 0,150252 & 46 & 0 & 46 & 8,03 \\
\hline
\end{tabular}

$$
C_{i^{*}}=S_{i-} / S_{i-}+S_{i^{*}} \text { and } 0<C_{i^{*}}<1, \mathrm{i}=1,2,3, \ldots \ldots, \mathrm{m} .
$$

It is clear that $\mathcal{C}_{i^{*}=1}$ if $A_{i}=A^{*}$ and $\mathcal{C}_{i^{*}}=0$ if $A_{i}=A^{-}$An alternative $A_{i}$ is closer to $A^{*}$ as $\mathcal{C}_{i^{*}}$ approaches to 1 .

\section{Step6. Rank the Preference Order}

A set of alternatives can now be preference ranked according to the descending order of $\boldsymbol{C}_{i^{*}}$.

The next section will provide the empirical results of the study.

\section{Findings}

TOPSIS ordered corporate governance ratings of BIST XKURY companies are reported in Table.3. The table also demonstrates the comparison of TOPSIS ordered corporate governance ratings with their standard forms. TOPSIS scores took the maximum value of 0.8087 for TSKB, whereas the minimum TOPSIS score is 0.1502 for CreditwestFactoring. The higher TOPSIS scores mean that the relevant companies are closer to the positive ideal solution represented by the score of " 1 ". As seen from Table.3, 35 companies have TOPSIS scores of more than 
0.50 , which are, compared to the remaining companies, closer to the positive ideal solution.

The last two columns of the table give the rank and score of the standard corporate governance ratings for companies, respectively. The number of place differences between TOPSIS based order and standard corporate governance rating order is also provided in the Table.

Having the place differences of zero, 14 companies keep the same places in both rankings. TSKB is at the top of both lists. Tupras is the second best company in TOPSIS list, with one place better ranking than in standard rating order. Conversely, Tav Airport, which has third place in TOPSIS list is one place behind in the standard list. There are other companies such as YapiKredi Bank, AnadoluEfes and Akbank that occupy similar positions in both lists, with just one or two place differences. There are, of course, some other companies with considerable divergent places in the lists. Logo, for example, is eight places ahead in TOPSIS list. Sekerbank, contrarily, is eight places behind in TOPSIS list.

Different ranking in the TOPSIS model emerges primarily because of the fact that the contribution of each sub-category value to the overall TOPSIS score depends on magnitude of each value relative to ideal positive and negative values of each sub-category. The sub-category values closer to ideal positive values will magnify the resulting TOPSIS scores of companies. Given the data-set provided in Table.2, for example, the largest values of each sub-categories form the ideal positive solution as $(9.468$, $9.947,9.92,9.782)$, which represents the TOPSIS score of "1". Then, companies with sub-category scores closer to those ideal positive values will have higher TOPSIS scores approaching " 1 ". For illustrative purposes, it will be proper to focus on the first two sub-categories, namely "shareholders" and "public disclosure and transparency", with the equal relative weights of $25 \%$. If there were a company in the list with the same value of, for example, "9" for both sub-categories, the contribution of each subcategory would be the same in computing the standard corporate governance rating. As for the TOPSIS score, however, the shareholder category would contribute more to the TOPSIS score of the company as for this category the value of " 9 " is much closer to the ideal positive value of " 9.468 " compared to the ideal positive value of " 9.947 " of the other sub-category. It is, then, clear that the companies in comparatively better places in the TOPSIS list have sub-category values closer to ideal positive values of each sub-category. If the sub-category values are further away from the ideal positive values, then the places of the companies are pulled down in the TOPSIS list.

\section{Conclusion}

Companies listed in BIST XKURY have overall corporate governance ratings computed as the weighted average of four corporate governance categories ratings. This study attempted to re-rank the corporate governance ratings of BIST XKURY companies for 2013 by use of TOPSIS method of ordering.

TOPSIS based ranking of corporate governance ratings displays differences from the standard rating ranking solely based on weighted average of four category ratings. In TOPSIS method of ordering, the contribution of each corporate governance sub-category to the overall score depends on the relative distance of the category rating to the positive and negative ideal solutions.

TOPSIS based ranking has richer information content as it is a dynamic process taking into consideration the interplay among all individual ratings. A score produced by TOPSIS method reflects the attributes of not only the company in question, but also the attributes of other companies concerned. Furthermore, TOPSIS method of ranking provides how close the companies to the positive and negative ideal solutions. The positive ideal solution is represented by score " 1 " whereas negative ideal solution has the score of " 0 ". The scores climbing up towards " 1 " feature that the companies are closer to the positive ideal solution. The lower the TOPSIS based scores, the closer the companies to the negative ideal solution.

The rank order of standard corporate governance ratings does present nothing but merely the ordered list of the ratings. As the ratings of companies are squeezed into narrower rating band of 8.00 to 10.00 , it is not possible to clearly evaluate the comparative strength of individual ratings in this list. However, even an individual score of TOPSIS order signals the position of a company relative to the ideal solutions. In other words, confirming the proposition in [20], this method produces scores that account for both the best and worst alternatives. Therefore, as stated earlier [20], TOPSIS model scores stand on their own as helpful decision-making tools.

TOPSIS order of BIST XKURY ratings reveals that there is a sizable position shift of more than five places for less than ten companies. Other companies retain either exact or similar places in both orders. The important contribution of TOPSIS method lies in the implication that individual scores offer. As for Turkish Industrial Development Bank (TSKB), the top company on both lists, it is reported, for example, that it has the corporate governance ranking of 9.403 . It is clear that this score is computed by taking the weighted average of sub-categories with no regard to the ratings of other companies in the index. The counterpart of this rating to the TOPSIS order is 0.808 . It is known that that score is the result the interaction of sub-category ratings of both TSKB and all other remaining 45 companies in the index. It can also be stated that the score diverges to a considerable extent from the ideal positive solution.

When the scores of the first (9.403) and the last company (8.03) are compared, it is seen that there is a rating difference of not more than $20 \%$ from the perspective of standard rating order. However, TOPSIS based ranking asserts completely different picture as there is about fourfold difference between the scores of the first company 
(0.808) and the last company (0.150). Then, seemingly similar performances within the standard perspective is sharply turned into huge differences in TOPSIS order. These are, undisputedly, clear examples that TOPSIS model of ranking has more to offer to potential decision makers.

\section{Acknowledgement}

This study is financially supported by the Turkish Academy of Sciences (TUBA)

\section{References}

[1] OECD (1998), Principles of Corporate Governance, www.oecd.org

[2] Onakoya, A. B. O., Ofoegbu, D. I. \&Fasanya, I. O, (2012). Corporate Governance and Bank Performance: A Pooled Study of Selected Banks in Nigeria, European Scientific Journal, Issue 8(28), pp 155-164.

[3] Shleifer, A., \&Vishny. R.W., (1997). A Survey of Corporate Governance. The Journal of Finance, Issue 52(2), pp 737 783

[4] OECD Principles of Corporate Governance, OECD Publishing, Revised Version, 2004.

[5] Needless, B. E., Turel, A., Sengur, E. D. \&Turel, A., (2012). Corporate Governance in Turkey: Issues and Practices of High Performance Companies. Accounting and Management Information Systems, Issue 11(4), pp 510-531.

[6] BIST, 2014. Corporate Governance Index. [Available at]: http://borsaistanbul.com/en/indices/bist-stockindices/corporate-governance-index.

[7] CMB, Capital Market Board of Turkey (2007) Communiqué on Principles Regarding Ratings and Agencies, Serial: VIII, No: 51 , http://www.spk.gov.tr/apps/teblig/displayteblig.aspx?id=313 \&ct=f\&action=displayfile\&ext=.pdf, January 18, 2014.

[8] Ergin, E., (2012). Corporate Governance Ratings and Market-based Financial Performance: Evidence from Turkey. International Journal of Economics and Finance, Issue 4(9), pp 61-68.

[9] Su H. A., Hsieh, C. H., Chang, C. Y. \& Lin, F., (2013). Corporate Governance Rating System in Taiwan with MultiCriteria Decision Making Methods. Contemporary Management Research, Issue 9(1), pp 3-12.
[10] Saha Ratting, (2014). Rating Definitions, http://www.saharating.com/Page.aspx?PageId=37, accessed January 18, 2014.

[11] Feng, C.M. \& Wang R.T., (2000). Performance Evaluation for Airlines Including the Consideration of Financial Ratios. Journal of Air Transport Management, 6, 133-142.

[12] Hosseini, S.H., Ezazi M. E., HeshmatiM. R., Reza.S. M. \&Moghadam,H. (2013). Top Companies Ranking Based on Financial Ratio with AHP-TOPSIS Combined Approach and Indices of Tehran Stock Exchange A Comparative Study.International Journal of Economics and Finance Vol. 5(3), pp.126-133.

[13] Onder, E., Tas, N. \&Hepsen, A. (2013). Performance Evaluation of Turkish Banks Using Analytical Hierarchy Process and TOPSIS Methods.Journal of International Scientific Publication: Economy \& Business, Volume 7(1), pp.470-503.

[14] Bhutio, P.W. \&Phipon, R. (2012), Application of Ahp and Topsis method for supplier selection problem. IOSR Journal of Engineering, Volume 2, Issue 10, pp 43-50

[15] Yukcu, S. \&Atagan, G. (2010). TOPSIS YöntemineGörePerformansDeğerleme.

MuhasebeveFinansmanDergisi, Sayı: 45, pp.28-35.

[16] Bulgurcu, B, K. (2012). Application of TOPSIS Technique for Financial Performance Evaluation of Technology Firms in Istanbul Stock Exchange Market. Procedia - Social and Behavioral Sciences 62 (2012) pp.1033 - 1040

[17] Conkar, K., Elitaş, C. \&Atar, G. (2011). IMKB KurumsalYönetimEndeksi'ndeki (XKURY) FirmalarınFinansalPerformanslarınınTopsisYöntemiileÖlçü müveKurumsalYönetimNotuileAnalizi, $\quad$ İstanbul Üniversitesi, İktisatMecmuasıDergisi, Cilt: 61(1), pp. 81115 ,

[18] Velasquez, M. \& Hester, P. T. (2013). An Analysis of MultiCriteria Decision Making Methods. International Journal of Operations Research, Vol. 10(2), pp.56-66.

[19] Hung C.C. \& Chen L.H. (2009). A Fuzzy TOPSIS Decision Making Model with Entropy Weight under Intuitionistic Fuzzy Environment. Proceedings of the International MultiConference of Engineers and Computer Scientists IMECS, Hong Kong.

[20] Hwang, C.L \& Yoon, K. (1981). Multiple Attribute Decision Making: Methods and Applications. New York: SpringerVerlag. 